ISSN: 2302-8556

E-Jurnal Akuntansi Universitas Udayana

Vol.25.1.Oktober (2018): 464-496

DOI: https://doi.org/10.24843/EJA.2018.v25.i01.p18

\title{
Pengaruh Modal Intelektual Pada Nilai Perusahaan Dengan Kinerja Keuangan Sebagai Variabel Mediasi
}

\author{
Ni Komang Sri Ariyani ${ }^{1}$ \\ Made Gede Wirakusuma ${ }^{2}$
}

${ }^{1}$ Fakultas Ekonomi dan Bisnis Universitas Udayana (Unud), Bali, Indonesia email: sriariyani13@gmail.com/Telp : 083789456156

${ }^{2}$ Fakultas Ekonomi dan Bisnis Universitas Udayana (Unud), Bali, Indonesia

\begin{abstract}
ABSTRAK
Penelitian ini bertujuan untuk menguji dan memberikan bukti empiris pengaruh modal intelektual pada nilai perusahaan dengan kinerja keuangan sebagai variabel mediasi. Penelitian ini menggunakan value added intellectual coefficients $\left(\mathrm{VAIC}^{\mathrm{TM}}\right.$ ) untuk menguji hubungan antara modal intelektual dengan nilai perusahaan. Nilai perusahaan diukur dengan harga nilai buku (PBV) dan kinerja keuangan perusahaan diukur dengan return on equity (ROE). Penelitian ini dilakukan pada perusahaan sub sektor farmasi yang terdaftar di BEI tahun 2012-2016. Jumlah sampel yang diambil sebanyak 40 perusahaan, dengan metode purposive sampling. Metode pengumpulan data dalam penelitian ini adalah observasi non partisipan. Teknik analisis data yang digunakan adalah analisis path.Hasil analisis menunjukkan bahwa modal intelekual berpengaruh positif pada kinerja keuangan, modal intelektual berpengaruh positif pada nilai perusahaan, kinerja keuangan berpengaruh positif pada nilai perusahaan serta hasil uji sobel menyatakan bahwa kinerja keuangan mampu memediasi hubungan antara modal intelektual pada nilai perusahaan.
\end{abstract}

Kata kunci: modal intelektual,nilai perusahaan,kinerja keuangan

\begin{abstract}
This study aims to test and provide empirical evidence of the influence of intellectual capital on corporate value with financial performance as a mediation variable. Company value is measured by book value (PBV) and company financial performance is measured by return on equity (ROE). This research was conducted at pharmaceutical sub-company listed on BEI year 2012-2016. The number of samples taken as many as 40 companies, with purposive sampling method. Data collection method in this research is nonparticipant observation. Data analysis technique used is path analysis. The result of the analysis shows that intellectual capital has positive effect on financial performance, intellectual capital has positive effect on firm value, financial performance has positive effect on firm value and test result stated that financial performance is able to mediate relationship between intellectual capital at firm value.
\end{abstract}

Keywords: intellectual capital, firm value, financial performance 


\section{PENDAHULUAN}

Seiring dengan persaingan bisnis yang semakin kompetitif menimbulkan dampak yang cukup signifikan terhadap pengelolaan serta penentuan strategi suatu bisnis. Selain itu adanya MEA (Masyarakat Ekonomi ASEAN) di Indonesia akan terus menuntut para pelaku bisnis dalam hal penciptaan nilai unggul agar tetap bisa bersaing di dunia bisnis yang semakin ketat kedepannya. Para pelaku bisnis mulai menyadari bahwa kemampuan bersaing tidak hanya terletak pada kepemilikan aktiva berwujud tetapi lebih pada inovasi, sistem informasi, pengelolaan organisasi dan sumber daya manusia yang dimiliki (Solikhah dkk, 2010). Oleh karena intensitas persaingan yang semakin meningkat dan mengarah terhadap teknologi yang semakin canggih dan bisnis yang semakin inovatif membuat perusahaan-perusahaan mengubah cara dalam menjalankan bisnis mereka.

Banyak perusahaan menerapkan prinsip padat karya (labor-based business), dalam artian semakin banyak karyawan yang dimiliki perusahaan maka akan meningkatkan produktivitas perusahaan sehingga perusahaan dapat berkembang. Agar perusahaan dapat terus bertahan dengan cepat maka perusahan perlu mengubah prinsip dari bisnis yang berdasarkan tenaga kerja menuju bisnis yang berdasarkan pengetahuan (knowledge based business) dengan karakteristik utama yaitu ilmu pengetahuan (Sawarjuwono dan Kadir, 2003).

Penerapan knowledge based business akan membuat penciptaan nilai suatu perusahaan berubah. Suatu perusahaan akan berkembang tergantung dari cara 
ISSN: 2302-8556

E-Jurnal Akuntansi Universitas Udayana Vol.25.1.Oktober (2018): 464-496

manajemen dalam memanfaatkan sumber daya yang dimiliki perusahaan. Nilai perusahaan merupakan harga saham yang bersedia di bayar oleh investor pada suatu perusahaan. Nilai perusahaan akan meningkat seiring dengan tingginya harga saham perusahaan.Mengoptimalkan nilai perusahaan merupakan hal yang sangat penting bagi perusahaan karena dengan mengoptimalkan nilai perusahaan maka kemakmuran pemegang saham yang merupakan tujuan utama perusahaan juga dapat dimaksimalkan (Juwariyah, 2014).

Berdasarkan resource based theory (RBT), perusahaan akan mencapai keunggulan apabila perusahaan memiliki sumber daya yang unggul. Asumsi RBT yaitu bagaimana perusahaan dapat bersaing dengan perusahaan lain untuk mendapatkan keunggulan kompetitif dengan mengelola sumber daya yang dimiliki sesuai dengan kemampuan perusahaan (Hadiwijaya 2013). Sumber ini berupa asset berwujud dan asset tak berwujud. Aset berwujud dapat dilihat dari neraca akuntansi sedangkan untuk mengidentifikasi asset tidak berwujud diperlukan suatu pengukuran. Pendekatan yang digunakan dalam penilaian dan pengukuran knowledge assets adalah modal intelektual (intellectual capital) (Petty dan Guthrie, 2000).

Salah satu area yang menarik akademisi maupun praktisi adalah hal yang terkait dengan kegunaan IC sebagai salah satu alat untuk menentukan nilai perusahaan (Edvinsson\& Malone 1997). Firer \& Williams (2003) mendefinisikan modal intelektualsebagai kekayaan perusahaan yang merupakan kekuatan dibalik penciptaan nilai perusahaan. Nilai suatu perusahaan tercermin dari harga yang dibayarkan investor atas sahamnya dipasar.Investor dapat mempertimbangkan rasio 
pasar modal seperti price to book value (PBV) sebab PBV mempunyai peran penting sebagai suatu pertimbangan bagi investor untuk memilih saham yang akan dibeli dan PBV dapat dijadikan indikator harga saham (Ahmed dan Nanda, 2004) serta relative stabil sehingga bisa dibandingkan dengan nilai pasar (Persson dan Stahlberg, 2006). Peningkatan selisih antara saham dengan nilai buku aktiva yang dimiliki perusahaan membuat modal intelektual menarik untuk diteliti. Adanya modal intelektual diyakini dapat berperan penting dalam meningkatkan nilai perusahaan. Sehingga untuk dapat meningkatkan nilai perusahaan, manajemen harus dapat memanfaatkan modal intelektualdengan efisien.

Terdapat banyak jenis pengukuran modal intelektual,hal ini dikarenakan belum adanya alat pengukuran yang dapat mengetahui keberadaan tingkat modal intelektual secara pasti di sebuah perusahaan. Pengukuran modal intelektual dalam penelitian ini menggunakan pengukuran metode value added intellectual coefficient $\left(\right.$ VAIC $\left.^{\mathrm{TM}}\right)$ yang dikembangkan oleh Pulic (1998) yang didesain untuk menyajikan informasi tentang efisiensi penciptaan nilai dari asset berwujud (tangible asset) dan asset tidak berwujud (intangible asset) yang dimiliki perusahaan. Keunggulan metode Pulic adalah kemudahan dalam memperoleh data yang digunakan dalam penelitian. VAIC $^{\mathrm{TM}}$ dianggap sebagai indikator yang cocok untuk mengukur modal intelektual pada riset empiris. VAIC ${ }^{\mathrm{TM}}$ menyediakan dasar ukuran yang standar dan konsisten, angka-angka keuangan standar yang terdapat dalam laporan keuangan perusahaan (Ulum, 2008). 
ISSN: 2302-8556

E-Jurnal Akuntansi Universitas Udayana Vol.25.1.Oktober (2018): 464-496

Penelitian tentang modal intelektual telah banyak dilakukan oleh peneliti diantaranya Chen et. al., (2005) melakukan penelitian mengenai hubungan modal intelektual terhadap nilai pasar dan kinerja perusahaan pada perusahaan public di Taiwan Stock Exchange menggunakan metode Value Added Intellectual Coefficient $\left(\mathrm{VAIC}^{\mathrm{TM}}\right)$. Hasil penelitian menunjukkan bahwa modal intelektual memiliki dampak positif terhadap nilai pasar dan kinerja keuangan. Penelitian juga membuktikan modal intelektual menjadi salah satu indikator untuk memprediksi kinerja perusahaan di masa mendatang.

Di Indonesia penelitian mengenai modal intelektual terhadap nilai perusahaan dan kinerja keuangan dilakukan oleh Sudibya dan Restuti (2014). Hasil penelitian menunjukkan hal serupa yaitu modal intelektual berpengaruh positif terhadap nilai perusahaan.Sedangkan hasil berbeda ditunjukkan oleh penelitian Widarjo (2011)dengan menggunakan metode $\mathrm{VAIC}^{\mathrm{TM}}$ mendapat hasil bahwa modal intelektual tidak berpengaruh signifikan terhadap nilai perusahaan.

Dengan adanya hasil penelitian yang masih belum konsisten mengenai pengaruh modal intelektualpada nilai perusahaan menandakan terdapat indikasi adanya research gap sehingga diperlukan adanya penelitian kembali. Peneliti menduga ketidakkonsistenan itu terjadi karena adanya pengaruh variabel lain yang memediasi pengaruh antara modal intelektualpada nilai perusahaan yaitu kinerja keuangan. Menurut Juwariyah (2014) perusahaan yang dapat memanfaatkan sumber daya intelektual yang dimiliki dengan efektif dan efisien maka kinerja keuangannya 
akan meningkat. Peningkatan kinerja keuangan akan di respon positif oleh pasar sehingga nilai perusahaan pun akan meningkat.

Studi terkini dilakukan oleh Neha dan Das (2017) meneliti pengaruh intellectual capital terhadap kinerja keuangan pada perusahaan farmasi di India menggunakan metode $\mathrm{VAIC}^{\mathrm{TM}}$. Hasil penelitian menunjukkan bahwa IC dapat menjelaskan profitabilitas serta disebutkan bahwa modal structural dan modal relasional merupakan faktor penting yang memiliki dampak besar pada profitabilitas. Sementara penelitian di Indonesia dilakukan oleh Baroroh (2013) meneliti analisis pengaruh modal intelektual terhadap kinerja keuangan pada 57 perusahaan manufaktur di Indonesia menggunakan metode $\mathrm{VAIC}^{\mathrm{TM}}$. Hasil penelitian menyatakan bahwa modal intelektual berpengaruh positif signifikan terhadap kinerja perusahaan saat ini dan di masa yang akan datang.

Hasil penelitian diatas menunjukkan adanya keterkaitan hubungan antara intellectual capital dengan kinerja perusahaan. Juwariyah (2014) berusaha menginvestigasi pengaruh IC terhadap nilai perusahaan dengan menggunakan kinerja keuangan sebagai variabel intervening. Objek penelitian pada perusahaan perbankan yang terdaftar di BEI pada tahun 2009-2012. Hasil penelitian menunjukkan bahwa IC memiliki hubungan positif terhadap kinerja keuangan dan kinerja keuangan dapat memediasi hubungan antara IC dengan nilai perusahaan.

Penelitan ini mereplikasi penelitian dari Juwariyah (2014) dengan tujuan untuk memperkuat hasil penelitian mengenai pengaruh modal intelektualterhadap kinerja keuangan dan pengaruh langsung dan tidak langsung modal 
ISSN: 2302-8556

E-Jurnal Akuntansi Universitas Udayana Vol.25.1.Oktober (2018): 464-496

intelektualterhadap nilai perusahaan. Penelitian ini penting untuk dilakukan karena hasil dari penelitian-penelitian terdahulu yang tidak konsisten yang kemungkinan diduga disebabkan oleh adanya variabel lain yang memediasi hubungan antara modal intelektualdengan nilai perusahaan yakni kinerja keuangan. Model VAIC $^{\mathrm{TM}}$ digunakan sebagai proksi untuk mengukur IC mengacu pada penelitian Firrer dan William (2003), Chen et al. (2005), Ulum (2007), dan Juwariyah (2014). Hal yang membedakan penelitian ini dengan sebelumnya adalah penggunaan ROE sebagai proksi atas kinerja keuangan perusahaan dan data yang digunakan terfokus pada perusahaan subsektor farmasi yang terdaftar di BEI periode 2012-2016.

Sub sektor farmasi dipilih sebagai objek penelitian karena perusahaan farmasi merupakan industri yang intensif melakukan penelitian, industri yang inovatif dan seimbang dalam penggunaan sumber daya manusia serta teknologi (Tarigan 2011).Pembaharuan produk dan inovasi sangat penting bagi keberlangsungan hidup perusahaan farmasi. Pembaharuan produk dan inovasi yang penting tersebut sangat bergantung pada modal intelektual yang dimiliki perusahaan (Sharabati et al. 2010).

Teori stakeholder menyatakan bahwa perusahaan bukanlah entitas yang hanya beroperasi untuk kepentingan sendiri, namun harus memberikan manfaat bagi stakeholder (Ghozali dan Chariri, 2007). Kelompok yang termasuk dalam stakeholder menurut Belkaoui (2003) adalah pemegang saham, karyawan, pelanggan, pemasok, kreditur, pemerintah dan masyarakat. Kelompok-kelompok tersebut dapat dikatakan stakeholder apabila memiliki kekuasaan ataupun kepentingan pada suatu perusahaan yang bersangkutan. Teori stakeholder beranggapan bahwa manajemen 
organisasi harus melakukan aktivitas-aktivitas yang dianggap penting oleh para stakeholder dan melaporkan kembali aktivitas tersebut kepada para stakeholder (Solikhah dkk, 2010). Seluruh stakeholder mempunyai hak untuk mengetahui informasi yang terkait dengan aktivitas suatu perusahaan.

Tujuan utama dari teori stakeholder adalah untuk membantu manajer perusahaan dalam memahami lingkungan stakeholder dan melakukan pengelolaan secara efektif hubungan-hubungan yang ada di lingkungan perusahaan (Ulum, 2009:5). Parastakeholder berperan penting untuk mempengaruhi manajemen dalam hal pemanfaatan potensi yang dimiliki perusahaan dengan maksimal. Dengan mengelola potensi yang dimiliki perusahaan secara efektif maka organisasi akan dapat menciptakan suatu nilai tambah yang nantinya akan mendorong kinerja keuangan perusahaan dimana hal tersebut merupakan orientasi para stakeholder dalam mengintervensi manajemen. Pada intinya, kunci utama keberhasilan perusahaan dalam meningkatkan nilainya terletak pada relasi yang dibangun antara perusahaan dan stakeholder.

Penjelasan mengenai hubungan $\mathrm{VAIC}^{\mathrm{TM}}$ dengan kinerja keuangan perusahaan menurut teori stakeholder harus dipandang dari kedua bidang, baik bidang etika (moral) maupun bidang manajerial. Bidang etika berargumen bahwa seluruh stakeholder memiliki hak untuk diperlakukan secara adil oleh organisasi dan manajer harus mengelola organisasi untuk keuntungan seluruh stakeholder (Deegan, 2004 dalam Ulum, 2007). Bidang manajerial berpendapat bahwa ketika para stakeholder berupaya untuk mengendalikan sumber daya organisasi, maka hal tersebut dilakukan 
ISSN: 2302-8556

E-Jurnal Akuntansi Universitas Udayana

Vol.25.1.Oktober (2018): 464-496

untuk meningkatkan kesejahteraan mereka yang tercermin dari tingkat return perusahaan yang tinggi (Watts dan Zimmerman, 1986 dalam Ulum, 2009).

Penciptaan nilai (value creation) dilakukan dengan memanfaatkan seluruh potensi yang dimiliki perusahaan. Pengelolaan yang baik atas seluruh potensi dapat menciptakan suatu value added yang kemudian akan mendorong meningkatnya kinerja keuangan dan pertumbuhan perusahaan sehingga nilai perusahaan di mata stakeholder akan meningkat. Sehingga value added dan return dapat menjelaskan kekuatan teori stakeholder dalam kaitannya dengan pengukuran kinerja perusahaan.

Resource-Based Theory (RBT) adalah suatu pemikiran yang berkembang dalam teori manajemen strategic dan keunggulan kompetitif perusahaan yang meyakini bahwa perusahaan akan mencapai keunggulan apabila memiliki sumber daya yang unggul (Solikhah dkk, 2010). Sebuah perusahaan dipersepsikan sebagai kumpulan asset maupun kemampuan berwujud dan tak berwujud (Firer dan Williams, 2003). Aset berwujud merupakan sumber daya yang dapat diidentifikasi dan dapat ditemukan di neraca laporan keuangan perusahaan. Sedangkan aset tidak berwujud adalah aset-aset penting yang dapat menciptakan keunggulan kompetitif suatu perusahaan. Teori ini menjelaskan bahwa kinerja perusahaan yang baik menunjukkan kemampuan perusahaan dalam penggunaan asset berwujud maupun asset tak berwujud secara efektif dan efisien.

Resource Based Theory (RBT) berpandangan bahwa sumber daya yang dimiliki perusahaan berpengaruh terhadap perkembangan perusahaan (Juwariyah,2014). Asumsi dari teori ini adalah bagaimana perusahaan dapat 
menciptakan nilai tambah melalui pengelolaan sumber daya yang dimilikinya. Salah satu sumberdaya yang dimiliki perusahaan dari asset tidak berwujud yaitu berupa modal intelektual.

Iranmahd et al. (2014) menyatakan bahwa modal intelektualtelah menjadi bagian penting bagi perusahaan. Menurut Bontis, et al. (2000), modal intelektual dapat diidentifikasi sebagai seperangkat aset tak berwujud (sumber daya, kemampuan, dan kompetensi) yang dapat mendorong kinerja organisasi dan penciptaan nilai. Definisi lain menurut Sawarjuwono dan Kadir (2003), modal intelektual dapat didefinisikan sebagai jumlah dari apa yang dihasilkan oleh tiga elemen utama organisasi (human capital, structural capital, customer capital) yang berkaitan dengan pengetahuan dan teknologi yang dapat memberikan nilai lebih bagi perusahaan berupa keunggulan bersaing organisasi. Rehman et al. (2011) mendefinisikan modal intelektual sebagai salah satu strategik aset yang sangat penting dalam pengetahuan berbasis ekonomi. Zeghal dan Maaloul (2010) mendefinisikan modal intelektualsebagai suatu pengetahuan perusahaan yang dapat digunakan dalam proses bisnis untuk menciptakan value added bagi perusahaan. Dari beberapa definisi tersebut, dapat disimpulkan bahwa modal intelektual merupakan seperangkat asset tak berwujud yang dimiliki oleh perusahaan berkaitan dengan pengetahuan dan teknologi yang berguna dalam penciptaan nilai lebih pada perusahaan berupa keunggulan bersaing organisasi.

Dengan demikian, elemen dari modal intelektual dapat dibedakan dalam tiga kategori yaitu pengetahuan yang berhubungan dengan karyawan (human capital), 
ISSN: 2302-8556

E-Jurnal Akuntansi Universitas Udayana

Vol.25.1.Oktober (2018): 464-496

pengetahuan yang berhubungan dengan infrastruktur perusahaan dan merupakan pendukung dari human capital (structural capital) serta pengetahuan yang berhubungan dengan mitra perusahaan (customer capital). Ketiga kategori tersebut membentuk suatu modal intelektualbagi perusahaan.

Saat ini upaya dalam mengetahuimodal intelektualdi sebuah perusahaan merupakan hal yang penting. Kesulitan dalam bidang modal intelektual adalah masalah dalam pengukuran.Model Pulic mengukur modal intelektual tidak secara langsung namun dengan mengusulkan koefisien Value Added Intellectual Coefficient (VAIC ${ }^{\mathrm{TM}}$ ) untuk menyediakan informasi tentang efisiensi penciptaan nilai dari aset berwujud dan tidak berwujud dalam suatu perusahaan. Pulic (2004) menegaskan, bahwa dibanding dengan metode pengukuran lainnya, VAIC ${ }^{\text {TM }}$ merupakan metode yang paling tepat untuk mengukur lingkup dan perbandingan, karena salah satu alasan utama adalah VAIC ${ }^{\text {TM }}$ dapat digunakan untuk mengukur efisiensi kinerja perusahaan. Beberapa alasan yang mendukung digunakannya VAIC ${ }^{\text {TM }}$ sebagai indikator dari modal intelektual (Firer dan Wiliam, 2003). VAIC ${ }^{\text {TM }}$ menyediakan dasar yang terstandarisasi dan konsisten dalam pengukuran sehingga angka VAICTM dapat dibandingkan antar perusahaan karena menyediakan standar konsistensi berdasarkan ukuran kinerja Intellectual Capital (IC). Data yang digunakan dalam pengukuran VAIC ${ }^{\text {TM }}$ berdasarkan data yang dapat ditemukan dalam laporan keuangan perusahaan yang telah diaudit dan bersifat obyektif serta dapat diandalkan. Pelaksanaan metode ini sederhana dan hasilnya dapat dengan mudah ditafsirkan. 
Metode ini paling sesuai dengan pemahaman kognitif stakeholder internal maupun eksternal.

Menurut Pulic (2004) VAIC ${ }^{\text {TM }}$ adalah sebuah prosedur analisis yang dirancang untuk memungkinkan manajemen, pemegang saham dan pemangku kepentingan lain yang terkait untuk secara efektif memonitor dan mengevaluasi efisiensi nilai tambah atau Value Added (VA) dengan total sumber daya perusahaan dan masing-masing komponen sumber daya utama. Nilai tambah adalah perbedaan antara pendapatan (OUT) dan beban (IN). Metode VAIC ${ }^{\text {TM }}$ mengukur efisiensi tiga jenis input perusahaan yaitu modal fisik; modal manusia; serta modal struktural.

Kinerja keuangan merupakan sebuah tampilan yang memberikan informasi terkait keadaan dan kondisi keuangan suatu perusahaan dalam periode tertentu atau dalam kurun waktu tertentu (Fauzi, 2016). Kinerja keuangan perusahaan merupakan gambaran dari kondisi keuangan perusahaan yang dianalisis menggunakan rasio keuangan (Tan et al. 2007). Sebagai emiten pada pasar modal perusahaan pada umumnya menerbitkan kinerja keuangan sebagai salah satu tanggung jawab terhadap pemegang saham (Arifin, 2016). Dengan menilai kinerja keuangan perusahaan, seorang investor dapat mengetahui keadaan atau kondisi suatu perusahaan.

Kinerja keuangan merupakan ukuran tertentu yang dapat menggambarkan pencapaian keberhasilan dari suatu perusahaan. Dari hasil analisis laporan keuangan akan dapat diketahui mengenai kinerja perusahaan terkait dengan tingkat kesehatan perusahaan, prestasi maupun kelemahan dari suatu perusahaan, sehingga adanya informasi tersebut akan sangat berguna sebagai bahan dalam pengambilan keputusan. 
ISSN: 2302-8556

E-Jurnal Akuntansi Universitas Udayana

Vol.25.1.Oktober (2018): 464-496

Menurut Halim (2015:213) profitabilitas merupakan salah satu indikator yang digunakan untuk mengukur kinerja keuangan perusahaan. Rasio profitabilitas akan menunjukkan kombinasi efek dari likuiditas, manajemen aset, dan utang pada hasilhasil operasi.

Pada penelitian ini kinerja keuangan perusahaan diukur dengan menggunakan proksi return on equity (ROE). Return on equity merupakan rasio profitabilitas yang digunakan untuk mengukur efektivitas perusahaan di dalam menghasilkan keuntungan dengan memanfaatkan total ekuitas yang dimiliki (Salim dan Karyawati, 2013). Semakin besar ROE menunjukkan bahwa kinerja perusahaan semakin baik karena pengembalian bersih yang lebih tinggi. Rasio kinerja ini adalah jumlah laba bersih yang dikembalikan sebagai persentase dari ekuitas pemegang saham.ROE mengungkapkan berapa banyak keuntungan perusahaan yang diterima dibandingkan dengan jumlah total ekuitas pemegang saham. Menurut Sudibya dan Restuti (2014) ROE menunjukkan seberapa baik suatu perusahaan menggunakan dana investasi untuk menghasilkan pertumbuhan pendapatan. ROE berguna untuk membandingkan profitabilitas antar perusahaan dengan membandingkan perusahaan dalam industri yang sama. Para pemegang saham atau investor memperhatikan ROE sebagai salah satu rasio keuangan yang penting. Investor yang akan membeli saham akan tertarik dengan ukuran profitabilitas tersebut (Pramudita, 2012). Perhitungannya dengan membagi laba bersih setelah pajak (earning after tax) dengan jumlah ekuitas (Pramelasari, 2010). 
Nilai perusahaan merupakan nilai jual suatu perusahaan dalam pasar modal (Aida dan Rahmawati, 2015). Nilai perusahaan merupakan pandangan investor atau pasar terhadap sebuah perusahaan yang kerap tercermin dari harga sahamnya. Nilai sebuah perusahaan ditentukan oleh kesuksesan atau kegagalan manajemen perusahaan dalam mengelola aset untuk menghasilkan laba (Tambunan, 2007). Ketika laba meningkat maka nilai perusahaan akan naik, hal tersebut akan diikuti oleh kenaikan harga saham perusahaan. Semakin tinggi harga saham maka semakin tinggi pula nilai perusahaan, sebaliknya semakin rendah harga saham maka nilai perusahaan juga rendah atau kinerja perusahaan kurang baik. Tujuan utama perusahaan menurut theory of the firm adalah untuk memaksimalkan nilai perusahaan (value of the firm). Memaksimalkan nilai perusahaan sangat penting bagi perusahaan, karena dengan memaksimalkan nilai perusahaan berarti juga memaksimalkan kemakmuran pemegang saham yang merupakan tujuan utama perusahaan (Salvatore, 2005). Nilai perusahaan dapat memberikan kemakmuran pemegang saham secara maksimal apabila harga saham meningkat.

Nilai perusahaan dalam penelitian ini diukur menggunakan Price to Book Value (PBV). Menurut Sunarsih dan Mendra (2012) PBV menggambarkan seberapa besar pasar menghargai nilai buku saham suatu perusahaan. Rasio PBV merupakan perbandingan antara harga saham dengan nilai buku ekuitas. Semakin tinggi rasio ini menunjukkan bahwa pasar semakin percaya akan prospek perusahaan.

Perusahaan yang berjalan dengan baik umumnya memiliki rasio price book value di atas satu. Nilai rasio ini mencerminkan bahwa nilai pasar lebih besar dari 
ISSN: 2302-8556

E-Jurnal Akuntansi Universitas Udayana

Vol.25.1.Oktober (2018): 464-496

pada nilai bukunya. Jika PBV di bawah satu, harga saham lebih rendah daripada nilai bukunya berarti terjadi undervalue (Juwariyah, 2014).

Kinerja keuangan merupakan sebuah gambaran atas kondisi keuangan suatu perusahaan dalam periode tertentu atau dalam kurun waktu tertentu. Chen et al. (2005) dalam penelitiannya menyatakan bahwa modal intelektual (intellectual capital) berpengaruh positif pada kinerja keuangan perusahaan. Perusahaan yang mampu mengelola pengetahuan dan sumber daya intelektualnya secara maksimal maka diyakini akan mampu menciptakan value added serta mampu menciptakan competitive advantage dengan cara melakukan inovasi dan pengembangan yang nantinya akan mendorong peningkatan kinerja perusahaan. Pendekatan berbasis sumber daya (resource-based theory) menyatakan bahwa untuk mencapai kinerja keuangan yang baik maka perusahaan harus dapat mengelola aset berwujud dan aset tidak berwujud. Hal tersebut selaras dengan teori stakeholder yang menyatakan bahwa manajemen organisasi diharapkan dapat melakukan aktivitas yang dianggap penting oleh para stakeholder dan melaporkan kembali aktivitas tersebut kepada para stakeholder karena seluruh stakeholder memiliki hak untuk mengetahui informasi mengenai aktivitas organisasi. Salah satu informasi yang bisa didapatkan adalah modal intelektual. Modal intelektualdiyakini dapat berperan penting bagi perusahaan dalam mendorong peningkatan kinerja keuangan dan nilai perusahaan.

Firer dan William (2003), Chen et al. (2005), Tan et al. (2007) dan Juwariyah (2014) telah membuktikan bahwa modal intelektual mempunyai pengaruh positif terhadap kinerja keuangan perusahaan. Dengan menggunakan metode $\mathrm{VAIC}^{\mathrm{TM}}$ yang 
diformulasikan oleh Pulic sebagai ukuran kemampuan intelektual perusahaan. Penelitian tersebut menunjukkan semakin tinggi VAIC ${ }^{\mathrm{TM}}$ maka semakin baik kinerja keuangan perusahaan.

$\mathrm{H}_{1}$ : Modal intelektual berpengaruh positif pada kinerja keuangan perusahaan

Menurut teori stakeholder, dijelaskan bahwa seluruh aktivitas perusahaan bermuara pada penciptaan nilai/value creation. Para stakeholder akan lebih menghargai perusahaan yang mampu menciptakan nilai, karena dengan penciptaan nilai yang baik maka perusahaan akan lebih mampu dalam memenuhi kepentingan para stakeholder. Dalam konteks intellectual capital, penciptaan nilai dilakukan dengan pemanfaatan unsur-unsur intellectual capital yaituhuman capital,structural capital dan customer capital dengan maksimal. Para stakeholder akan lebih menghargai perusahaan yang memiliki IC yang unggul karena IC yang unggul akan membantu perusahaan untuk memenuhi kepentingan seluruh stakeholder. Sebagai salah satu stakeholder perusahaan, para investor di pasar modal akan menunjukkan apresiasi atas keunggulan IC yang dimiliki perusahaan dengan berinvestasi pada perusahaan tersebut. Pertambahan investasi akan berdampak pada naiknya nilai perusahaan.

Penelitian yang dilakukan oleh Chen et al. (2005) membuktikan bahwa modal intelektual berpengaruh positif terhadap kinerja dan nilai pasar perusahaan. Apabila perusahaan dapat mengelola modal intelektualdengan baik maka hal ini akan meningkatkan persepsi pasar terhadap nilai perusahaan. Hasil serupa didapatkan pada 
ISSN: 2302-8556

E-Jurnal Akuntansi Universitas Udayana Vol.25.1.Oktober (2018): 464-496

penelitian yang dilakukan oleh Sudibya dan Restuti (2014) menyatakan bahwa modal intelektual berpengaruh positif pada nilai perusahaan yang diukur dengan PBV.

$\mathrm{H}_{2}$ : Modal Intelektual berpengaruh positif pada nilai perusahaan

Semakin baik kinerja suatu perusahaan maka akan semakin baik pula prospek perusahaan di masa mendatang yang artinya semakin baik juga nilai suatu perusahaan. Kinerja keuangan merupakan gambaran dari kondisi perusahaan yang di analisis menggunakan rasio keuangan. Dari hasil analisis laporan keuangan dengan menggunakan rasio tersebut dapat diketahui tingkat keberhasilan manajemen dalam mengelola aset dan modal yang dimiliki oleh perusahaan. Menurut Fakhruddin (2008:4) peningkatan laba merupakan salah satu faktor penting bagi terciptanya keunggulan daya saing perusahaan secara berkelanjutan. Apabila perusahaan mampu untuk meningkatkan laba, maka harga saham juga akan meningkat. Peningkatan harga saham merupakan wujud apresiasi investor terhadap kinerja perusahaan serta keyakinan akan peningkatan kinerja kedepannya yang tentunya akan memberikan nilai tambah bagi perusahaan.

Penelitian yang dilakukan oleh Hidayati (2010) membuktikan bahwa kinerja perusahaan yang di proksikan dengan profitabilitas dengan variabel pengukuran ROE berpengaruh positif terhadap nilai perusahaan dengan menggunakan PBV. Hal ini menunjukkan bahwa semakin naik kinerja keuangan maka kemungkinan akan terjadi kenaikan terhadap nilai perusahaan.Dan sebaliknya apabila kinerja keuangan menurun maka nilai perusahaan juga akan mengalami penurunan. Penelitian selanjutnya oleh Martikarini (2011) mendapat hasil sejalan dengan penelitian 
Hidayati (2010). Penelitian ini menunjukkan hasil bahwa return on equity (ROE) berpengaruh secara signifikan terhadap nilai perusahaan yang diukur dengan price to book value (PBV). Kinerja keuangan yang baik dan keuntungan yang tinggi akan memberikan gambaran bahwa perusahaan memiliki suatu prospek yang baik. Hal ini akan menarik perhatian investor sehingga meningkatkan nilai perusahaan karena investor menjadi tertarik untuk berinvestasi pada perusahaan tersebut.

$\mathrm{H}_{3}$ : Kinerja keuanganberpengaruh positif pada nilai perusahaan

Dalam teori berbasis sumber daya (resource-based theory) terdapat asumsi bahwa perusahaan dapat bersaing secara kompetitif apabila perusahaan tersebut dapat mengelola dan memanfaatkan sumber daya berupa asset berwujud dan asset tak berwujud dengan efektif dan efisien. Ketika sumber daya dikelola secara efektif dan efisien hal tersebut akan mendorong adanya peningkatan kinerja bagi perusahaan. Peningkatan kinerja ini akan mendapat respon positif dari stakeholder, salah satunya adalah investor. Nilai perusahaan dapat tercermin dari harga saham perusahaan. Semakin baik respon stakeholder maka akan semakin baik nilai perusahaan. Salah satu asset penting perusahaan dalam mendukung aktivitas sebuah perusahan untuk mendorong peningkatan kinerja dan nilai perusahaan adalah berupa modal intelektual (intellectual capital).

Penelitian yang dilakukan oleh Belkaoui (2003), Chen et al. (2005) dan Tan et al. (2007) telah membuktikan bahwa modal intelektual berpengaruh positif terhadap kinerja dan nilai perusahaan. Bertolak belakang dengan penelitian tersebut dimana penelitian Lestari dan Sapitri (2016) tidak berhasil membuktikan bahwa modal 
ISSN: 2302-8556

E-Jurnal Akuntansi Universitas Udayana

Vol.25.1.Oktober (2018): 464-496

intelektual berpengaruh terhadap nilai perusahaan. Dalam penelitiannya Lestari dan Sapitri (2016) memandang adanya faktor lain yang mempengaruhi hubungan tersebut. Oleh karena itu, peneliti menambahkan variabel interveningyaitu kinerja keuangan dalam memediasi hubungan modal Intelektual. Hal ini didukung oleh Sunarsih dan Mendra (2011) dinyatakan bahwa kinerja keuangan sebagai mediator variable dapat memediasi hubungan antara modal intelektual dan nilai perusahaan.

$\mathrm{H}_{4}$ : Kinerja keuangan memediasi hubungan antara modal intelektualdan nilai perusahaan.

\section{METODE PENELITIAN}

Penelitian ini dilakukan pada perusahaan go-publik subsektor industri farmasi seluruh Indonesia yang terdaftar dalam Bursa Efek Indonesia. Penelitian ini berfokus pada pengaruh modal intelektual terhadap nilai perusahaan dengan kinerja keuangan sebagai variabel mediasi pada tahun 2012-2016. Sub sektor farmasi dipilih sebagai objek penelitian karena perusahaan farmasi merupakan industri yang intensif melakukan penelitian, industri yang inovatif dan seimbang dalam penggunaan sumber daya manusia serta teknologi (Tarigan 2011).Pembaharuan produk dan inovasi sangat penting bagi keberlangsungan hidup perusahaan farmasi. Pembaharuan produk dan inovasi yang penting tersebut sangat bergantung pada modal intelektual yang dimiliki perusahaan (Sharabati et al 2010).

Populasi dalam penelitian ini adalah seluruh perusahaan farmasi yang

terdaftar di Bursa Efek Indonesia tahun 2012-2016.Teknik pengambilan sampel 
dalam penelitian ini adalah purposive sampling. Purposive sampling merupakan teknik pengambilan sampel dengan menggunakan kriteria tertentu.

Tabel 1. Proses Seleksi Sampel berdasarkan Kriteria

\begin{tabular}{clc}
\hline \multicolumn{1}{c}{ Kriteria Sampel } & Jumlah \\
\hline 1 & $\begin{array}{l}\text { Perusahaan go publik yang terdaftar di BEI pada subsektor farmasi } \\
\text { periode tahun 2012-2016 }\end{array}$ & 9 \\
2 & $\begin{array}{l}\text { Perusahaan yang tidak menerbitkan laporan tahunan secara berturut- } \\
\text { turut selama periode tahun 2012-2016 }\end{array}$ & $(1)$ \\
Sampel yang digunakan & 8 \\
Jumlah pengamatan selama tahun 2012-2016 & 40 \\
\hline Sumber: Data diolah, 2018
\end{tabular}

Teknik pengumpulan data dalam penelitian ini yaitu dengan metode observasi non partisipan. Sugiyono (2014) menyatakan bahwa observasi non partisipan adalah teknik pengumpulan data dengan observasi atau pengamatan dimana peneliti tidak terlibat langsung dan hanya sebagai pengamat independen. Metode ini digunakan karena peneliti memperoleh data dengan pengumpulan melalui pengamatan dari buku, jurnal,skripsi serta mengakses website resmi Bursa Efek Indonesia melalui www.idx.co.id guna memperoleh informasi mengenai laporan tahunan keuangan perusahaan.

Untuk menguji pengaruh variabel mediasi digunakan metode analisis jalur (path analysis). Analisis jalur merupakan perluasan dari analisis regresi linier berganda atau penggunaan analisis regresi untuk menaksir hubungan kausalitas antar variabel yang telah ditetapkan sebelumnya berdasarkan teori (Utama, 2016:159).

Uji sobel merupakan alat analisis untuk menguji signifikansi dari hubungan tidak langsung antar variabel independen dengan variabel dependen yang dimediasi 
oleh variabel mediator (Preacher dan Hayes, 2004). Uji Sobel diformulasikan dengan rumus sebagai berikut :

$$
\mathrm{t}=\frac{\mathrm{ab}}{\mathrm{Sab}}
$$

dengan,

$$
\mathrm{Sab}=\sqrt{b^{2} S a^{2}+a^{2} S b^{2}+S a^{2} S b^{2}}
$$

Keterangan :

a = koefisien regresi dari variabel independen $(X)$ terhadap variabel mediasi $(\mathrm{Z})$

$\mathrm{b}=$ koefisien regresi dari variabel mediasi $(\mathrm{Z})$ terhadap variabel dependen $(\mathrm{Y})$

$\mathrm{Sa}=$ standar error koefisien a

$\mathrm{Sb}=$ standar error koefisien $\mathrm{b}$

Hasil analisis akan membandingkan nilai $t_{\text {hitung }}$ dengan $t_{\text {tabel }}$. Jika $t_{\text {hitung }}$ lebih besar dari $t_{\text {tabel }}$ dengan tingkat signifikansi 0.05 yaitu sebesar 1,96 maka dapat dikatakan terjadi pengaruh mediasi (Ghozali, 2013).

\section{HASIL PENELITIAN DAN PEMBAHASAN}

Deviasi standar menunjukkan seberapa luas atau rentangan antara nilai minimum dengan nilai maksimum dari masing-masing variabel. Output statistik deskriptif diolah dengan menggunakan SPSS Statistics 18.0 for Windows. Adapun hasil statistik deskriptif setiap variabel dapat dilihat pada tabel 2 .

\section{Tabel 2.}

\section{Hasil Statistik Deskriptif Variabel Penelitian}

\begin{tabular}{cccccc}
\hline Variabel & N & Min. & Maks. & Rata-rata & Simpangan Baku \\
\hline $\mathbf{Y}$ & 40 & 0.2740 & 25.2970 & 3.714025 & 4.4135542 \\
$\mathbf{X}$ & 40 & -.3000 & 10.0800 & 3.344750 & 2.5033741 \\
$\mathbf{Z}$ & 40 & -9.3256 & 46.5562 & 17.331933 & 13.5815220 \\
\hline
\end{tabular}

Sumber:Data diolah, 2018 
Berdasarkan Tabel 2., diketahui bahwa terdapat tiga variabel penelitian, yaitu nilai perusahaan yang diproksikan dengan PBV, modal intelektual dan kinerja keuangan yang diproksikan dengan ROE. Beberapa penjelasan mengenai hasil perhitungan statistik bahwa variabel nilai perusahaan (Y) dengan nilai rata-rata (mean) sebesar 3,714 dan simpangan baku (standar deviasi) sebesar 4,413. Nilai minimum pada variabel nilai perusahaan diperoleh pada Taisho Pharmaceutical IndonesiaTbk. sebesar 0,2740, sedangkan nilai maksimum diperoleh pada Indofarma (Persero)Tbk. sebesar 25,297.

Variabel Modal Intelektual (VAIC) (X) dengan nilai rata-rata (mean) sebesar 3,3447 dan simpangan baku (standar deviasi) sebesar 2,5033.Nilai minimum pada variabel modal intelektual diperoleh pada Kimia Farma (Persero) Tbk. sebesar 0,3000 sedangkan nilai maksimum diperoleh pada Taisho Pharmaceutical IndonesiaTbk. sebesar 10,0800.

Variabel Kinerja Keuangan (ROE) $(\mathrm{Z})$ dengan nilai rata-rata (mean) sebesar 17,3319 dan simpangan baku (standar deviasi) sebesar 13,58152. Nilai minimum pada variabel kinerja keuangan diperoleh pada Indofarma (Persero) Tbk. sebesar -0,932 sedangkan nilai maksimum diperoleh pada Taisho Pharmaceutical IndonesiaTbk. sebesar 46,556.

Perhitungan koefisien path dilakukan dengan analisis regresi melalui software SPSS 18.0 for Windows, diperoleh hasil yang ditunjukan pada Tabel 3. berikut. 
ISSN: 2302-8556

E-Jurnal Akuntansi Universitas Udayana

Vol.25.1.Oktober (2018): 464-496

Tabel 3.

Hasil Analisis Jalur Struktur 1

\begin{tabular}{|c|c|c|c|c|c|}
\hline & \multicolumn{2}{|c|}{$\begin{array}{l}\text { Unstandardized } \\
\text { Coefficients }\end{array}$} & \multirow{2}{*}{$\begin{array}{c}\text { Standardized } \\
\text { Coefficients } \\
\text { Beta }\end{array}$} & \multirow[b]{2}{*}{$\mathbf{T}$} & \multirow[b]{2}{*}{ Sig. } \\
\hline & B & Std. Error & & & \\
\hline (Constant) & .206 & .156 & & 1.320 & .195 \\
\hline Modal Intelektual (VAIC) & .415 & .153 & .402 & 2.706 & .010 \\
\hline F Hitung & & & & & 7,321 \\
\hline Signifikansi & & & & & 0,010 \\
\hline $\mathrm{R}_{1}$ Square & & & & & 0,162 \\
\hline Adjusted $\mathrm{R}_{1}$ Square & & & & & 0,139 \\
\hline
\end{tabular}

Berdasarkan hasil analisis jalur substruktur 1 seperti yang disajikan pada

Tabel 2., maka persamaan strukturalnya adalah sebagai berikut :

$$
\begin{aligned}
& \mathrm{ROE}=\beta_{1} \mathrm{VAIC}^{\mathrm{TM}}+\mathrm{e}_{1} \ldots \ldots \\
& \mathrm{ROE}=0,402 \mathrm{VAIC}^{\mathrm{TM}}+\mathrm{e}_{1}
\end{aligned}
$$

Nilai $\beta_{1}$ sebesar 0,402 memiliki arti bahwa modal intelektual berpengaruh positif pada kinerja keuangan, dengan kata lain jika faktor modal intelektual meningkat sebesar satu satuan maka kinerja keuangan akan meningkat sebesar 0,402.

Berdasarkan hasil analisis statistik dalam penelitian ini menunjukkan bahwa hipotesis pertama $\left(\mathrm{H}_{1}\right)$ dapat diterima dan menyimpulkan bahwa modal intelektual yang diproksikan dengan VAIC mempunyai pengaruh signifikan dan memiliki hubungan positif terhadap kinerja keuangan yang diproksikan dengan ROE dengan pengaruh sebesar 0,402 atau sebesar 40,2 persen. Hasil analisis ini mengindikasikan bahwa semakin baik perusahaan dalam mengelola modal intelektual yang dimiliki, maka akan memberikan peningkatan pada kinerja keuangan perusahaan. 
Tabel 4.

Hasil Analisis Jalur Struktur 2

\begin{tabular}{|c|c|c|c|c|c|}
\hline & \multicolumn{2}{|c|}{$\begin{array}{l}\text { Unstandardized } \\
\text { Coefficients }\end{array}$} & \multirow{2}{*}{$\begin{array}{c}\text { Standardized } \\
\text { Coefficients } \\
\text { Beta }\end{array}$} & \multirow[b]{2}{*}{$\mathbf{T}$} & \multirow[b]{2}{*}{ Sig. } \\
\hline & B & Std. Error & & & \\
\hline (Constant) & .133 & .118 & & 1.131 & .265 \\
\hline Modal Intelektual (VAIC) & .463 & .124 & .445 & 3.743 & .001 \\
\hline Kinerja Keuangan (ROE) & .454 & .120 & .451 & 3.793 & .001 \\
\hline F Hitung & & & & & 23,738 \\
\hline Signifikansi & & & & & 0,000 \\
\hline $\mathrm{R}_{2}$ Square & & & & & 0,562 \\
\hline Adjusted $R_{2}$ Square & & & & & 0,538 \\
\hline
\end{tabular}

Berdasarkan hasil analisis jalur substruktur 2 seperti yang disajikan pada Tabel 4. maka persamaan strukturalnya adalah sebagai berikut :

$$
\begin{array}{r}
\mathrm{PBV}=\beta_{2} \mathrm{VAIC}^{\mathrm{TM}}+\beta_{3} \mathrm{ROE}+\mathrm{e}_{2} \ldots \\
\mathrm{PBV}=0,445 \mathrm{VAIC}^{\mathrm{TM}}+0,451 \mathrm{ROE}+\mathrm{e}_{2}
\end{array}
$$

Nilai $\beta_{2}$ 0,445 memiliki arti bahwa modal intelektual berpengaruh positif pada nilai perusahaan, dengan kata lain jika faktor modal intelektual meningkat sebanyak satu satuam maka nilai perusahaan akan meningkat sebesar 0,445.

Nilai $\beta_{3} 0,451$ memiliki arti bahwa kinerja keuangan berpengaruh positif pada nilai perusahaan, dengan kata lain jika faktor kinerja keuangan meningkat sebanyak satu satuan maka nilai perusahaan akan meningkat sebesar 0,451.

Berdasarkan hasil analisis statistik dalam penelitian ini menunjukkan bahwa hipotesis kedua $\left(\mathrm{H}_{2}\right)$ dapat diterima dan menyimpulkan bahwa modal intelektual yang diproksikan dengan VAIC mempunyai pengaruh signifikan dan memiliki hubungan positif terhadap nilai perusahaan yang diproksikan dengan PBV dengan pengaruh 
ISSN: 2302-8556

E-Jurnal Akuntansi Universitas Udayana

Vol.25.1.Oktober (2018): 464-496

sebesar 0,445 atau 44,5 persen. Hasil ini mengindikasikan bahwa pasar telah memberikan penilaian yang lebih tinggi pada perusahaan yang memiliki modal intelektual yang tinggi.

Berdasarkan hasil analisis statistik dalam penelitian ini menunjukkan bahwa hipotesis ketiga $\left(\mathrm{H}_{3}\right)$ dapat diterima dan menyimpulkan bahwa kinerja keuangan yang diproksikan dengan ROE mempunyai pengaruh signifikan dan memiliki hubungan positif terhadap nilai perusahaan yang diproksikan dengan PBV dengan pengaruh sebesar 0,451 atau sebesar 45,1 persen.Hasil penelitian mengindikasikan bahwa semakin meningkat kinerja keuangan perusahaan, maka akan mengakibatkan nilai perusahaan semakin meningkat.

Berdasarkan model substruktur 1 dan substruktur 2, maka dapat disusun model diagram jalur akhir. Sebelum menyusun model diagram jalur akhir, terlebih dahulu dihitung nilai standar eror sebagai berikut :

$$
P e_{i}=\sqrt{1-R_{i}^{2}}
$$

Substruktur 1:

$$
\begin{aligned}
& \mathrm{ROE}=0,402 \mathrm{VAIC}^{\mathrm{TM}}+\mathrm{e}_{1} \\
& \text { Pengaruh error }\left(\mathrm{Pe}_{1}\right)=\sqrt{1-R_{1}^{2}} \\
& \mathrm{Pe}_{1}=\sqrt{1-0,162}=0,915
\end{aligned}
$$

Substruktur 2:

$$
\begin{aligned}
& \mathrm{PBV}=0,445 \mathrm{VAIC}^{\mathrm{TM}}+0,451 \mathrm{ROE}+\mathrm{e}_{2} \\
& \text { Pengaruh error }\left(\mathrm{Pe}_{2}\right)=\sqrt{1-R_{2}{ }^{2}} \ldots \ldots \ldots
\end{aligned}
$$




$$
\mathrm{Pe}_{2}=\sqrt{ } 1-0,562=0,662
$$

Berdasarkan perhitungan pengaruh error (Pei), didapatkan hasil pengaruh error $\left(\mathrm{Pe}_{1}\right)$ sebesar 0,915 dan pengaruh error $\left(\mathrm{Pe}_{2}\right)$ sebesar 0,662. Hasil koefisien determinasi total adalah sebagai berikut :

$$
\begin{aligned}
\mathrm{R}_{\mathrm{m}}^{2} & =1-\left(\mathrm{Pe}_{1}\right)^{2}\left(\mathrm{Pe}_{2}\right)^{2} \\
& =1-(0,915)^{2}(0,662)^{2} \\
& =1-(0,837)(0,438) \\
& =1-0,366=0,634
\end{aligned}
$$

Nilai determinasi total sebesar0,634 mempunyai arti bahwa sebesar 63,4\% variasi Nilai perusahaan (PBV)dipengaruhi oleh variasi Modal Intelektual (VAIC) dan Kinerja Keuangan (ROE), sedangkan sisanya sebesar 36,6\% djelaskan oleh faktor lain yang tidak dimasukkan ke dalam model.

Perhitungan pengaruh antar variabel dirangkum dalam Tabel 5. berikut:

\section{Tabel 5.}

Pengaruh Langsung dan Pengaruh Tidak Langsung serta PengaruhTotal Variabel Penelitian

\begin{tabular}{ccccc}
\hline & $\begin{array}{c}\text { Pengaruh } \\
\text { Variabel }\end{array}$ & $\begin{array}{c}\text { Pengaruh } \\
\text { Langsung }\end{array}$ & $\begin{array}{c}\text { Pengaruh Tidak Langsung } \\
\text { Melalui Kinerja Keuangan } \\
(\text { ROE })\end{array}$ & Pengaruh Total \\
$(\mathbf{Y 1})(\beta \mathbf{1} \mathbf{x} \boldsymbol{3})$ & 0,402 \\
\hline$\beta \mathbf{1}$ & $\mathrm{X} \rightarrow \mathrm{Z}$ & 0,402 & - & 0,626 \\
$\beta \mathbf{2}$ & $\mathrm{X} \rightarrow \mathrm{Y}$ & 0,445 & 0,181 & 0,451 \\
\hline $\mathbf{3}$ & $\mathrm{Z} \rightarrow \mathrm{Y}$ & 0,451 & - & \\
\hline
\end{tabular}

Sumber: Data diolah, 2018

Hasil pada tabel 5. menunjukkan bahwa pengaruh langsung variabel modal intelektual pada nilai perusahaan memiliki nilai koefisien beta sebesar 0,445 , namun 
pengaruh tidak langsung yang dimediasi oleh kinerja keuangan menunjukkan nilai koefisien beta sebesar 0,181 dengan pengaruh total sebesar 0,626.

Besarnya pengaruh tidak langsung modal intelektual pada nilai perusahaan adalah 0,181 yang berarti kinerja keuangan merupakan variabel yang memediasi hubungan modal intelektual dan nilai perusahaan. Hasil penelitian ini berhasil membuktikan dugaan peneliti mengenai adanya pengaruh kinerja keuangan yang memediasi hubungan modal intelektual dan nilai perusahaan sehingga hipotesis empat $\left(\mathrm{H}_{4}\right)$.

Uji Sobel dirumuskan dengan persamaan berikut dan dapat dihitung dengan menggunakan aplikasi Microsoft Excel 2007. Bila nilai kalkulasi Z lebih besar dari 1,96 (dengan tingkat kepercayaan 95 persen), maka variabel mediator dinilai secara signifikan memediasi hubungan antara variabel terikat dan variabel bebas.

$$
\begin{aligned}
& Z=\frac{a b}{\sqrt{b^{2} S a^{2}+a^{2} S b^{2}+S a^{2} S b^{2}}} \ldots \ldots . \\
& \text { Sig }=(1-\operatorname{NORMDIST}(Z))+2)) .
\end{aligned}
$$

Keterangan :

$$
\begin{aligned}
& \mathrm{a}=0,402 \\
& \mathrm{~S}_{\mathrm{a}}=0,153 \\
& \mathrm{~b}=0,451 \\
& \mathrm{~S}_{\mathrm{b}}=0,120 \\
& \mathrm{Z}=\frac{0,402 \times 0,451}{\sqrt{(0,451)^{2}(0,153)^{2}+(0,402)^{2}(0,120)^{2}+(0,153)^{2}(0,120)^{2}}} \\
& \mathrm{Z}=\frac{0,1813}{\sqrt{0,0048+0,0023+0,0003}}
\end{aligned}
$$




$$
\begin{aligned}
& Z=\frac{0,1813}{\sqrt{0,0074}} \\
& Z=2,1040 \\
& \text { Sig }=(1-\text { NORMDIST }(2,1552))+2)) \\
& \text { Sig }=0,0354
\end{aligned}
$$

Tabel 6.

Hasil Uji Sobel

\begin{tabular}{rc}
\hline Nilai Z & Sig \\
\hline 2,1040 & 0,035 \\
\hline Sumber: Data diolah, 2018 &
\end{tabular}

Sumber: Data diolah, 2018

Berdasarkan hasil Uji Sobel pada Tabel menunjukkan bahwa hasil nilai Z = $2,1040>1,96$ dengan tingkat signifikansi $0,035<0,05$ yang berarti variabel mediator yakni kinerja keuangan dinilai secara positif signifikan memediasi hubungan antara Modal Intelektual (VAIC)terhadapNilai perusahaan (PBV).

\section{SIMPULAN}

Berdasarkan hasil penelitian yang diperoleh melalui pengujian statistik serta pembahasan seperti yang telah diuraikan pada bab sebelumnya, maka dapat disimpulkan bahwa modal intelektual berpengaruh positif pada kinerja keuangan. Hasil penelitian mengindikasikan bahwa semakin baik perusahaan dalam mengelola modal intelektual yang dimiliki, maka akan memberikan peningkatan pada kinerja keuangan perusahaan.

Modal intelektual berpengaruh positif pada nilai perusahaan. Hasil penelitian mengindikasikan bahwa pasar telah memberikan penilaian yang lebih tinggi pada perusahaan yang memiliki modal intelektual yang tinggi. Temuan penelitian ini mengindikasikan bahwa penghargaan pasar pada suatu perusahaan tidak hanya 
ISSN: 2302-8556

E-Jurnal Akuntansi Universitas Udayana

Vol.25.1.Oktober (2018): 464-496

didasarkan pada sumber daya fisik yang dimiliki saja tetapi juga pada modal intelektual yang dimiliki oleh perusahaan

Kinerja keuangan berpengaruh positif pada nilai perusahaan. Hasil penelitian mengindikasikan bahwa semakin meningkat kinerja keuangan perusahaan, maka akan mengakibatkan nilai perusahaan semakin meningkat.

Kinerja keuangan mampu memediasi hubungan antara modal intelektual dan nilai perusahaan.

Beberapa saran yang dapat diberikan untuk penelitian selanjutnya adalah lokasi penelitian terbatas hanya pada perusahaan sub sektor farmasi yang terdaftar di Bursa Efek Indonesia. Peneliti selanjutnya agar dapat dilakukan penelitian pada sektor perusahaan yang berbeda, seperti sektor pertambangan, sektor pertanian, sektor properti, sektor perdagangan, dan lain-lain.

Pengukuran modal intelektual dapat menggunakan metode selain metode $\mathrm{VAIC}^{\mathrm{TM}}$ agar hasilnya dapat diperbandingkan dan mempertimbangkan proksi indikatorindikator lainnya dalam menentukan nilai perusahaan seperti Tobin's dan Market to Book Value sehingga memungkinkan hasil yang lebih luas.

Periode pengamatan dan jumlah sampel yang kecil dapat menurunkan keterwakilan hasil uji hipotesis. Penelitian selanjutnya diharapkan dilakukan pada rentang waktu yang lebih panjang sehingga diharapkan dapat menggambarkan kondisi perusahaan yang lebih baik. 


\section{REFERENSI}

Ahmed, P. dan S. Nanda. 2001. Style Investing: Incorporating Growth Characteristics in Value Stocks. The Journal of Portofolio Management, 27 (3), hal.47-59.

Aida, Rahma Nurul dan Rahmawati,E. 2015, Pengaruh Modal Intelektual dan Pengungkapannya Terhadap Kinerja Perusahaan. JurnalAkuntansi \& Investasi, 16 (2), hal.96-109.

Arifin, Jauhar. 2016. Pengaruh Intellectual Capital terhadap Kinerja Keuangan pada Perusahaan Sektor Perbankan yang Terdaftar di Bursa Efek Jakarta Periode 2008-2012. Jurnal AdBispreneur, 1(3),hal.195-206.

Baroroh, Niswah. 2013.Analisis Pengaruh Modal Intelektual Terhadap Kinerja Keuangan Perusahaan Manufaktur di Indonesia. Jurnal Dinamika Akuntansi,5 (2), pp. 172-182.

Belkaoui, Ahmed Riahi. 2003. Intellectual Capital and Firm Performance of US Multinational Firm: A Study of The Resource-Based and Stakeholder View. Journal of Intellectual Capital, 4 Issue. 2 pp. 215-226.

Bontis, Nick, William Chua Chong Keow dan Staney Richardson. 2000. Intellectual Capital and Business Performance in Malaysian Industries. Journal of Intellectual Capital.

Bontis, Nick. 2000. Assesing Knowledge Assets : A Review of the Models Used to Measure Intellectual Capital. School of Bussiness Mc Master University Hal 124.

Chen, M.C., S.J Cheng, Y. Hwang. 2005. An Empirical Investigation of Relationship Between Intellectual Capital and Firms Market Value and Financial Performance. Journal of Intellectual Capital, 6 (2), pp. 159-176.

Edvinsson, L., and M.Malone. 1997. Intellectual Capital: Realizing Your Company's True Value by Finding Its Hidden Brainpower. Harper Collins Publishers Inc. New York.

Fakhruddin, Hendy M. 2008. Go Public: Strategi Pendanaan dan Peningkatan Nilai Perusahaan. Jakarta: PT. Elex Media Computindo.

Fauzi, Achmad. 2016. Analisis Pengaruh Intellectual Capital terhadap Nilai Perusahaan dengan Kinerja Keuangan sebagai Variabel Intervening. Skripsi. Universitas Islam Negeri Syarif Hidayatullah, Jakarta. 
ISSN: 2302-8556

E-Jurnal Akuntansi Universitas Udayana

Vol.25.1.Oktober (2018): 464-496

Firrer,S.,and Williams, S.M. 2003. Intellectual Capital and Traditional Measures of Corporate Performance. Journal of Intellectual Capital, 4(3), pp 348-360.

Ghozali, Adrian dan Hatane, Saarce Elsye. 2014. Pengaruh Intellectual Capital Terhadap Kinerja Keuangan dan Nilai Perusahaan Khususnya di Industri Keuangan dan Industri Pertambangan yang terdaftar di Bursa Efek Indonesia tahun 2008-2012. Business Accounting Review, 2 (2)hal. 208-217.

Hadiwijaya, Rendy Cahyo. 2013. Pengaruh Modal Intelektual terhadap Nilai Perusahaan dengan Kinerja Keuangan sebagai Variabel Intervening. Skripsi. Universitas Diponegoro, Semarang.

Halim, Abdul. 2015. Manajemen Keuangan Bisnis. Edisi pertama. Jakarta: Mitra Wacana Media

Hidayati, Eva Eko. 2010. Analisis Pengaruh DER, DPR, ROE dan Size Terhadap PBV Perusahaan Manufaktur yang Listing di BEI Tahun 2005-2007. Jurnal Bisnis dan Strategi, 19 (2), hal.166-174.

Iranmahd, M., Moeinaddin,M.,Shahmoradi,N.,and Heyrani, F. (2014). The Effect of Intellectual Capital on Cost of Finance and Firm Value. International Journal of Academic Research in Accounting, Finance and Management Sciences, 4 (2), hal. $1-8$.

Juwariyah, Esti Suhernanik. 2014. Pengaruh Intellectual Capital terhadap Nilai Perusahaan melalui Kinerja Keuangan sebagai Variabel Intervening. Skripsi. Universitas Airlangga, Surabaya.

Lestari, Nanik dan Rosi Candra Sapitri. 2016. Pengaruh Intellectual Capital terhadap Nilai Perusahaan. Jurnal Akuntansi, Ekonomi dan Manajemen Bisnis, 4 (1) hal.28-33.

Martikarini, Nani. 2011. Pengaruh Profitabilitas, Kebijakan Hutang dan Kebijakan Dividen terhadap Nilai Perusahaan Manufaktur yang Terdaftar di Bursa Efek Indonesia Periode 2009-2011. Jurnal Akuntansi Universitas Gunadharma.

Neha, Smriti and Niladri Das. 2017. Impact of Intellectual Capital on Business Performance: Evidence from Indian Pharmaceutical Sector. Journal of Intellectual Capital, 15 (1), pp. 232-243. 
Persson, E. dan C.Stahlberg. 2006. P/E and EV/EBITDA Investment Strategies vs the Market - a Study of Market Efficiency. Master Karya Akhir. Linkoping University.

Petty,P. dan J. Guthrie. 2000. Intellectual Capital Literature Review: Measurement, Reporting and Management.Journal of Intellectual Capital, 1 (2) pp.155-175.

Pramelasari, Y. M. 2010. Pengaruh Intellectual Capital Terhadap Nilai Pasar dan Kinerja Keuangan. SkripsiSarjana Akuntansi pada Fakultas Ekonomi Universitas Diponegoro, Semarang.

Pramuditha, G. 2012. Pengaruh Intellectual Capital terhadap Nilai Pasar dan Kinerja Keuangan Perusahaan Perbankan yang Terdaftar di BEI tahun 2008-2010. Skripsi. Sarjana Akuntansi pada Fakultas Ekonomi Universitas Diponegoro, Semarang.

Preacher, K.J. dan Hayes, A.F. 2004. SPSS and SAS Procedures For Estimating Indirect Effects in Simple Mediation Models. Behaviour Research Methods, Instruments \& Computer, 36 (4), pp.717-731.

Pulic. 2004. Intellectual Capital: Does It Create or Destroy Value? Measuring Business Excellent. 8 (1) pp. 62-68.

Rehman, W.U., Muhammad Ilyas and Hafeez ur Rehman. 2011. Intellectual Capital Perfor-mance and Its Impact on Financial Returns of Companies: An Empirical Study from Insu-rance Sector of Pakistan. African Journal of Business Management, 5, (20), pp. 8041-8049.

Salim, Selvi Meliza dan Glorida Karyawati.2013. Pengaruh Modal Intelektual terhadap Kinerja Keuangan. Journal of Bussines and Enterpreneurship, 1 (2), hal. 74-91.

Salvatore, Dominick. 2005. Managerial Economics. Fifth Edition. Singapore: Thomson Learning.

Sawarjuwono, Tjiptohadi dan Agustine Prihatin Kadir. 2003. Intellectual Capital: Perlakuan, Pengukuran dan Pelaporan (Sebuah Library Research).Jurnal Akuntansi dan Keuangan, 5 (1), hal. 35-37.

Sharabati, A.A.A.,S.N.Jawad, and N.Bontis. 2010. Intellectual Capital and Business Performance in the Pharmaceutical Sector of Jordan. Management Decision, 48 (1), pp.105-131. 
ISSN: 2302-8556

E-Jurnal Akuntansi Universitas Udayana Vol.25.1.Oktober (2018): 464-496

Solikhah, Badingatus,Abdul Rohman, dan Wahyu Meiranto. 2010. Implikasi Intellectual Capital terhadap Financial Performance, Growth dan Market Value; Studi Empiris dengan pendekatan Simplistic Spesification. Makalah Disampaikan dalam Simposium Nasional Akuntansi XIII. Purwokerto: 13-15 Oktober.

Sudibya, Diva Ciciliya Nunki dan Restuti, MI Mitha Dwi. 2014. "Pengaruh Modal Intelektual Terhadap Nilai Perusahaan dengan Kinerja Keuangan sebagai Variabel Intervening”. Benefit Jurnal Manajemen dan Bisnis, 18 (1), hal. 14-29.

Sunarsih, Ni Made dan Ni Putu Yuria Mendra. 2012. Pengaruh Modal Intelektual terhadap Nilai Perusahaan dengan Kinerja Keuangan sebagai Varibel Intervening pada Perusahaan yang Terdaftar di Bursa Efek Indonesia. Makalah Disampaikan dalam Simposium Nasional Akuntansi XV, Banjarmasin, 20-23 September.

Tambunan, A.P. 2007. Menilai Harga Wajar Saham (Stock Valuation). Jakarta: PT. Elex Media.

Tan, Hong Pew, Plowman, David \& Hancock Phil. 2007. Intellectual Capital and Financial Return of Companies. Journal of Intellectual Capital,8 (1), pp. 76-95.

Tarigan, Timotius. 2011. Analisis Pengaruh Intellectual Capital terhadap Kinerja Perusahaan Sektor Farmasi ang Terdaftar di Bursa Efek Indonesia Tahun 20062010.Skripsi. Universitas Diponogoro, Semarang.

Ulum, Ihyaul. 2007. Pengaruh Intellectual Capital terhadap Kinerja Keuangan Perusahaan Perbankan di Indonesia. Tesis. Program Studi Magister Sains Akuntansi.Universitas Diponegoro.

Widarjo, Wahyu. 2011. Pengaruh Modal Intelektual dan Pengungkapan Modal Intelektual pada Nilai Perusahaan. Makalah Disampaikan dalam Simposium Nasional Akuntansi XIV, Banda Aceh : 21-22 Juli. 